\title{
The response of the Gulf of Mexico to wind and heat flux forcing: What has been learned in recent years?
}

\author{
JORGE ZAVALA-HIDALGO, ROSARIO ROMERO-CENTENO and ADRIANA MATEOS-JASSO \\ Centro de Ciencias de la Atmósfera, Universidad Nacional Autónoma de México, Circuito de la Investigación \\ Cientifica s/n, Ciudad Universitaria, 04510 México, D.F. \\ Corresponding author: J. Zavala-Hidalgo; e-mail: jzavala@atmosfera.unam.mx
}

STEVEN L. MOREY
Center for Ocean-Atmospheric Prediction Studies, Florida State University, 2000 Levy Avenue, Building A,
Suite 292, Tallahassee, FL 32306-2741, USA

BENJAMÍN MARTÍNEZ-LÓPEZ

Centro de Ciencias de la Atmósfera, Universidad Nacional Autónoma de México, Circuito de la Investigación Cientifica s/n, Ciudad Universitaria, 04510 México, D.F.

Received December 9, 2013; accepted June 2, 2014

\begin{abstract}
RESUMEN
La dinámica del Golfo de México (GoM) se asocia frecuentemente con la Corriente del Lazo y los remolinos que se desprenden de ésta, los cuales son altamente energéticos y ocasionan corrientes intensas que pueden penetrar varios cientos de metros en la columna de agua. Sin embargo, hay regiones en el GoM y periodos de tiempo en que el forzamiento atmosférico local juega un papel importante en su dinámica y termodinámica. La circulación en las plataformas, particularmente en la interna, es generada principalmente por viento y tiene estacionalidad, ya que cambia de dirección a lo largo del año y tiene algunos periodos de condiciones favorables para el afloramiento/hundimiento. La circulación generada por el viento se vincula con el transporte de aguas con diferentes características de temperatura y salinidad. La variabilidad interanual de la circulación en las plataformas está asociada con la variabilidad interanual de la circulación atmosférica. Se ha identificado que la variabilidad intraestacional de los patrones de viento modifica considerablemente la ocurrencia de afloramientos y hundimientos. Debido a la forma y tamaño del GoM, cuando la circulación en una plataforma ocurre en sentido horario, puede darse en sentido opuesto en otras plataformas. El ancho de las plataformas en el GoM es variable: la plataforma oeste de Florida, la de Texas-Louisiana y el Banco de Campeche miden más de $200 \mathrm{~km}$, en tanto que las más angostas son las de Veracruz y Tabasco. Otra consecuencia de la fisiografía del GoM y el forzamiento del viento es el desarrollo de transportes perpendiculares a la plataforma en el sur de la Bahía de Campeche, el sur de la plataforma de Texas y al sureste del Mississippi, los cuales a su vez varían a lo largo del año. El GoM es afectado durante el otoño-invierno (desde septiembre hasta abril) por frentes fríos provenientes del noroeste de Estados Unidos, los cuales tienen asociados vientos fuertes, secos y fríos que mezclan sus aguas y generan intensos flujos de calor sensible y latente del mar hacia la atmósfera. Estos vientos también enfrían el GoM debido a la mezcla de aguas cálidas de la superficie con aguas subsuperficiales de menor temperatura. Durante el verano, los ciclones tropicales que cruzan el GoM afectan su circulación y los afloramientos costeros.
\end{abstract}

\footnotetext{
ABSTRACT

The Loop Current and its shed eddies dominate the circulation and dynamics of the Gulf of Mexico (GoM) basin. Those eddies are strongly energetic and are the cause of intense currents that may penetrate several hundred meters deep. However, there are regions in the GoM and periods of time in which the local
} 
atmospheric forcing plays an important role in its dynamics and thermodynamics. The circulation on the shelves, and particularly on the inner shelf, is mainly wind-driven with seasonality, changing direction during the year with periods of favorable upwelling/downwelling conditions. The wind-driven circulation is associated with the transport of waters with different temperature and salinity characteristics from one region to another. The interannual variability of the circulation on the shelves is linked to the atmospheric variability. Intraseasonal variability of the wind patterns considerably affects the likelihood and magnitude of upwelling and downwelling. The geometry of the GoM is such that large-scale winds may drive opposing upcoast/ downcoast currents along different parts of the curving coast, resulting in convergence or divergence zones. The width of the shelves in the GoM is variable;while the West Florida Shelf, the Texas-Louisiana shelf and the Campeche Bank are more than $200 \mathrm{~km}$ wide, they are narrower near Veracruz and Tabasco. Another consequence of the GoM physiography and the wind forcing is the development of cross-shelf transports in the southern Bay of Campeche, the southern Texas shelf and southeast of the Mississippi river, which in turn vary during the year. During autumn-winter (from September to April), the GoM is affected by cold fronts coming from the northwest United States, which are associated with strong, dry, and cold winds that mix its waters and generate large sensible and latent heat fluxes from the ocean to the atmosphere. These frontal passages also cool the GoM surface waters due to mixing with lower temperature subsurface waters. During summer, tropical cyclones crossing the GoM can dramatically affect circulation and coastal upwelling.

Keywords: Gulf of Mexico, ocean surface forcing, upper ocean layer.

\section{Introduction}

The Gulf of Mexico (GoM) is a semienclosed sea with deep areas and narrow as well as wide continental shelves (Fig. 1). The GoM has been the object of many studies, so it is important to periodically review and synthesize recent results and to identify knowledge gaps, warranting investigation in the near future. The purpose of this manuscript is to review what has been learned in recent years related to the local surface forcing of the GoM, both by heat fluxes and wind stress. Some historic publications have reviewed general aspects of the GoM and others have been more topically focused. Examples of these review publications are the very ambitious and successful Fishery Bulletin 89 (Galtsoff, 1954) that summarizes the knowledge on the Gulf at that time, including

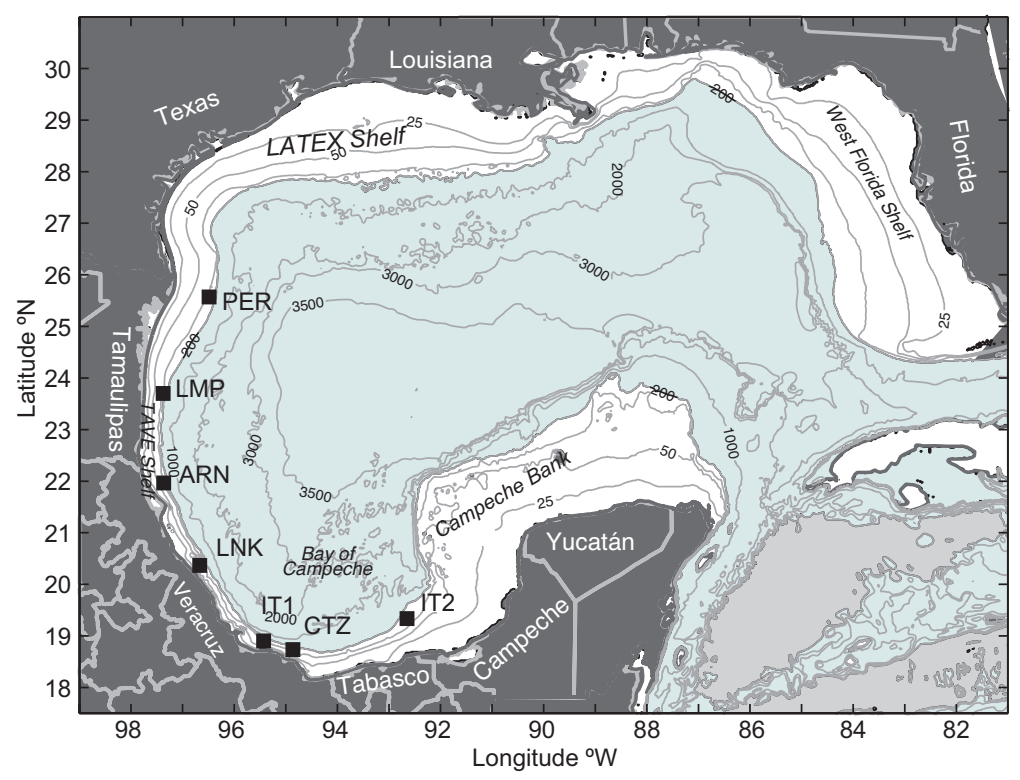

Fig. 1. The Gulf of Mexico. States and names of shelves are indicated. Position of the Canek Project moorings along the $130 \mathrm{~m}$ isobath are also indicated (Drubranna et al., 2011). 
information of its marine meteorology, geological features, the physics and chemistry of its waters, its physical oceanography, and a detailed review of its biology. Another classical document is a book edited by Capurro and Reid (1972), which includes chapters related to the physical phenomena affecting the GoM that were studied at that time. Recently, the American Geophysical Union published a monograph (Sturges and Lugo-Fernández, 2005), which includes articles on the current knowledge of the Gulf in selected topics.

Recent events, like the Deep Water Horizon oil spill of 2010, opened discussion on several aspects of the GoM dynamics, like the influence of the wind on the oil spill advection and dispersion, the transport from deep-water to coastal areas, the role of wind waves in the mixing and dispersion of the oil, the mixed layer dynamics, etc., which brought renewed attention to these ocean processes (Liu et al., 2011). Perhaps bolstered by this event, substantial work has been undertaken on a new generation of very high resolution numerical models used to simulate biogeochemical and biological processes, which are strongly influenced by the ocean-atmosphere interaction. The present work summarizes recent advances in understanding the influence of heat and momentum fluxes (wind stress) on the GoM dynamics and thermodynamics. The annual cycle of heat fluxes and winds is described, emphasizing the response of the mixed layer depth, sea surface temperature (SST), and entrainment. The influence of the wind stress and wind stress curl on the circulation of the GoM, particularly on the shelves, coastal upwelling and cross-shelf transports, including the seasonality and interannual variability (in some cases), are also described.

\section{The winds in the Gulf of Mexico}

Although the low level winds over the GoM are very important for the ocean circulation, surface fluxes, mixed layer properties, and generation of wind waves, there are relatively few studies about them (e.g., DiMego et al., 1976; Gutiérrez and Winant, 1996; Wang et al., 1998). However, several other studies have analyzed specific aspects of the winds over the GoM that are related with particular ocean processes (e.g. Oey, 1995; Zavala-Hidalgo et al., 2003; Morey et al., 2005; Nowlin et al., 2005; Vázquez de la Cerda et al., 2005; Martínez-López and Zavala-Hidalgo, 2009; Dubranna et al., 2011; Ma-
teos-Jasso et al., 2012; Pérez-Brunius et al., 2013). Here, a general description of the characteristics of the wind and surface fluxes in the GoM is presented, and other aspects that need to be analyzed or updated are suggested.

\subsection{Seasonal variability of the winds}

The winds in the GoM have strong variability over different time and space scales, with important seasonality. The GoM is affected by intense winds caused by tropical cyclones that cross it between May and November and by cold fronts reaching the area mainly between September and May. Winds that are not associated with these strong events are weaker, but are important for upwelling, mixed layer depth, surface fluxes, circulation (particularly on the shelves), development of wind waves, etc.

Winds over the GoM are part of the trade winds and have a large influence on the North American continent. Based on long-term monthly means computed from the QuikSCAT/SeaWinds scatterometer data, it is observed that, during summer, the wind turns toward the north in the northwestern Gulf due to the influence of the North Atlantic semi-permanent atmospheric high-pressure system over the northeastern region (Fig. 2). This pattern is probably reinforced by the high temperature over land driving a monsoonal effect. Between May and August, winds are more intense in the western Gulf and are weaker in the northeast, with this pattern more evident in July (Fig. 2). In September, this wind pattern changes because the cold fronts associated with atmospheric high-pressure systems coming from the northwestern United States begin to reach the GoM and the semi-permanent high-pressure system over the Atlantic Ocean shifts northeastward. During autumn, the long-term monthly mean wind direction in the northern Gulf is mainly westward, with a small southward component. In the Bay of Campeche an intense southward wind component develops, mainly in the western side of the bay, favored by a mountain blocking effect caused by the Sierra Madre Oriental in Mexico that directs the wind through the Isthmus of Tehuantepec where the mountain chain has a low altitude passage. In addition, the lower pressure in the Gulf of Tehuantepec also favors southward winds (Romero-Centeno et al., 2003). This pattern remains until February and it is more pronounced in December (Fig. 2). 

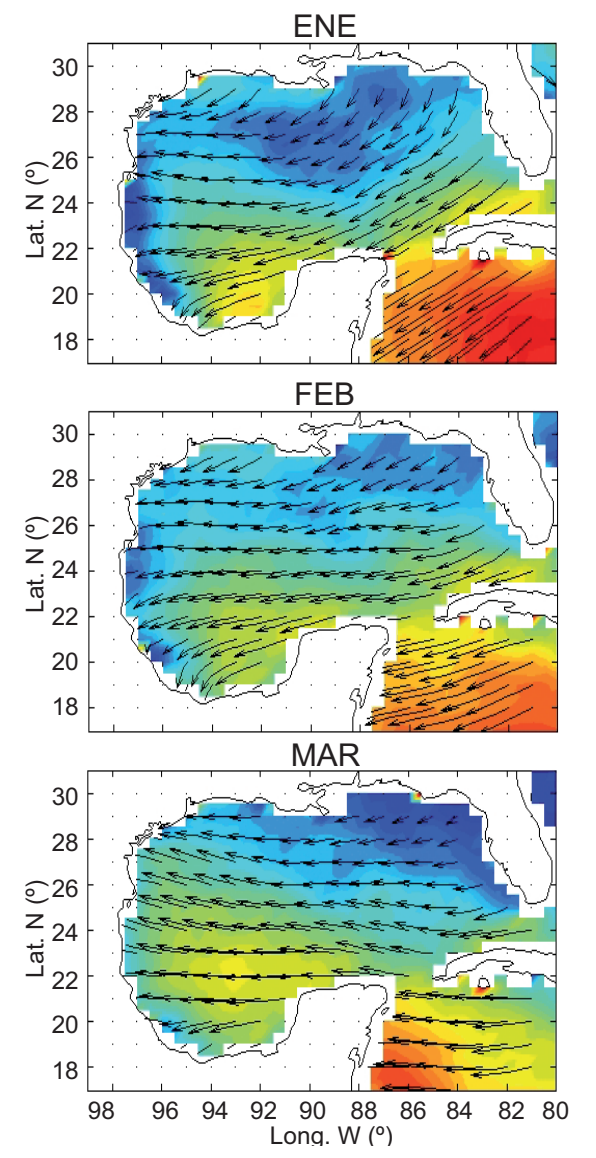

Fig. 2. Long-term monthly means (1999-2006) of the winds in the Gulf of Mexico based on Qscat/SeaWinds data. Contours indicate the scalar mean wind speed $\left(\mathrm{ms}^{-1}\right)$ according to the color bar and arrows indicate the wind direction. (Continues.)

The time-mean wind stress curl is negative (anticyclonic) north of $23{ }^{\circ} \mathrm{N}$ and positive (cyclonic) south of that latitude, mainly in the Campeche Bay. The zero wind stress curl contour line has a southeast-northwest orientation (Gutiérrez de Velasco and Winant, 1996, their Figs. 5-8). The annual cycle of the wind stress curl is characterized by the displacement of the zero contour line, moving southward during spring and summer and northward in autumn and winter. The largest negative values of the wind stress curl are observed in the northeastern GoM in summer and they became smaller in winter. During autumn and winter, positive values are larger in the western Bay of Campeche (Gutiérrez de Velasco and Winant, 1996, their Figs. 5-8).

\subsection{High frequency winds}

Every year several easterly waves are generated over west Africa and the eastern tropical Atlantic. These perturbations travel from east to west as Rossby
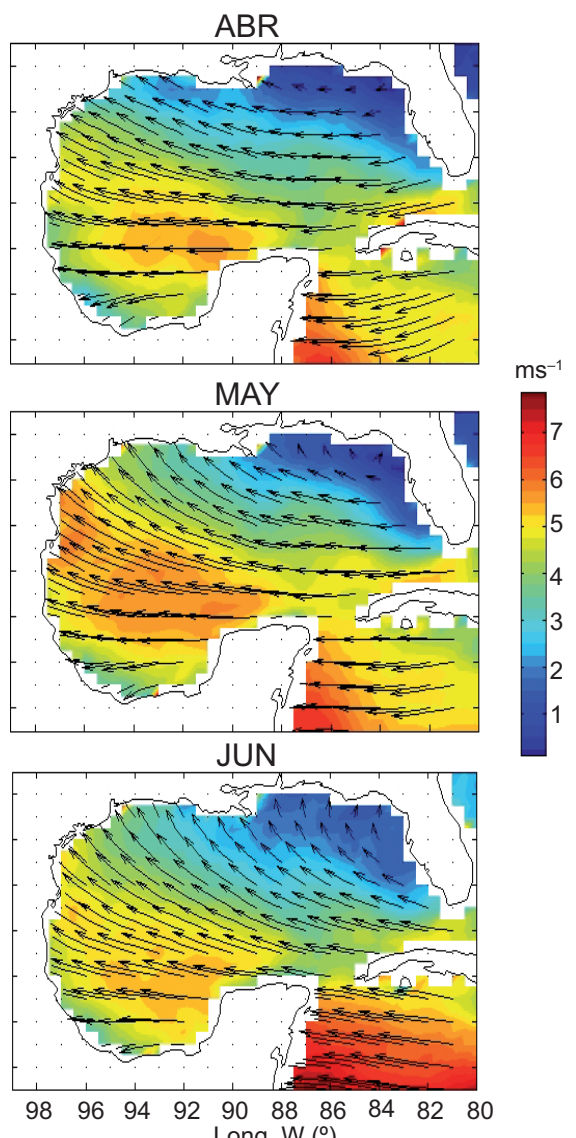

waves, with wavelengths of about 2000 to $5000 \mathrm{~km}$ and phase speed between 8 and $12 \mathrm{~ms}^{-1}$. In some cases, these waves develop into tropical storms or hurricanes (Burphee, 1974; Diedhiou et al., 1999), but not all the tropical cyclones are generated by easterly waves. In the tropical North Atlantic basin there is an annual cumulative average of 11.3 named systems of which 6.2 are hurricanes (www.nhc.noaa.gov). Not all the easterly waves reach the GoM because, in many cases, they turn northeastward crossing the major Caribbean Islands or turn even before the Caribbean Sea. When easterly waves reach the GoM they affect the stratification and shelf circulation, because they produce changes in the direction and intensity of the winds (Mateos-Jasso et al., 2012).

The cold fronts, or northers, can occur all year round in the GoM but with different intensity, frequency, and southward penetration. They have associated strong northerly winds and cold and dry air masses. During summer they are very rare, while 

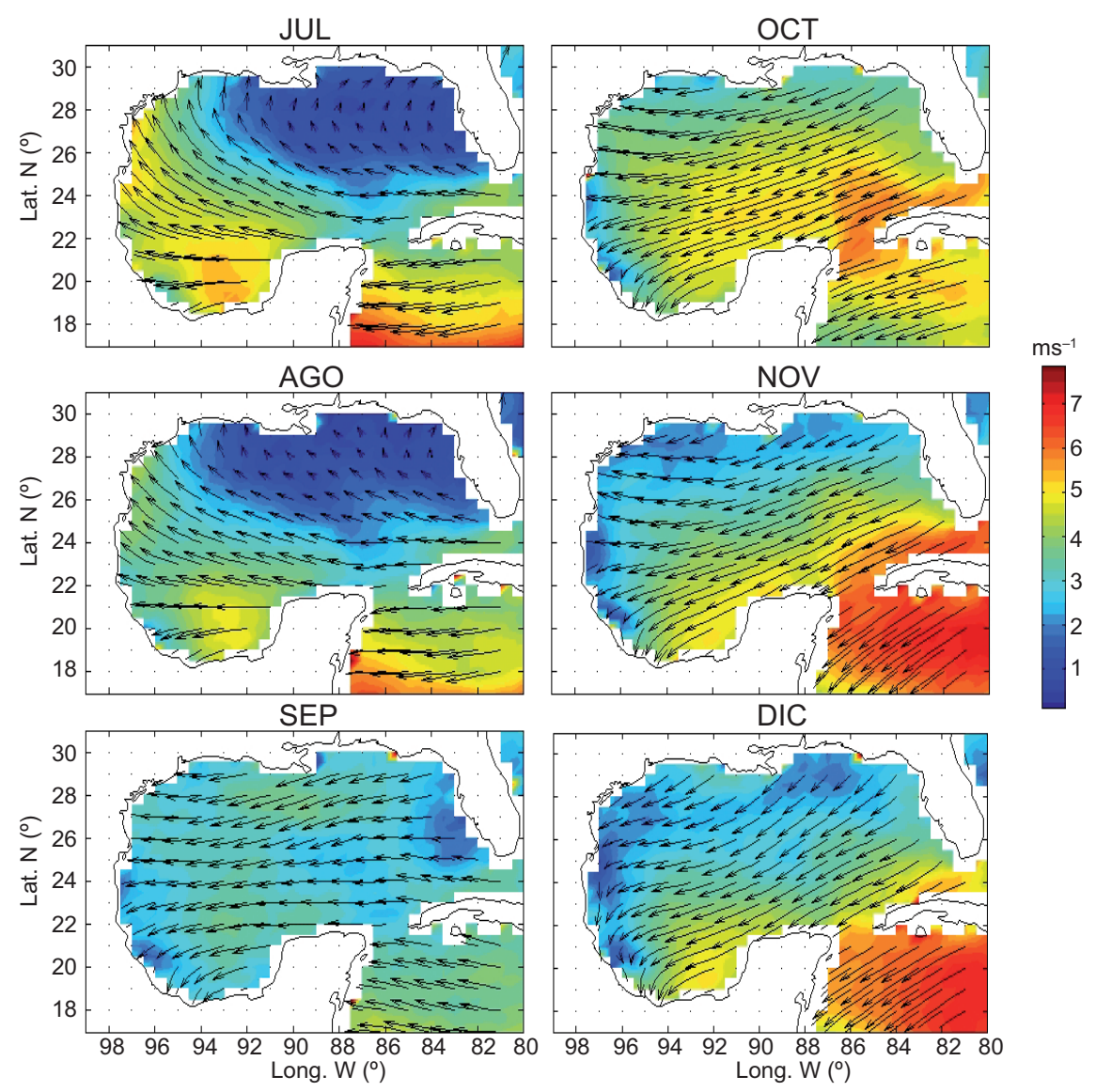

Fig. 2. (Continuation.)

in autumn-winter are more frequent. The transition between these two seasons occurs in late September and is very sharp. These strong fronts can continue to occur until spring, but diminishing in numbers and intensity through April and May (DiMego et al., 1976). Not all the fronts cross the whole GoM; most of them only reach the northern part. The duration of the strong winds and cold air associated with the passage of fronts also decreases southward. Therefore, the number of observed fronts per year and their duration depends on the region of the GoM (Fig. 3) (DiMego et al.,1976). Another characteristic of the northers is the occurrence during autumn, in some years, of long periods of continuous northerly winds offshore of Veracruz (Mateos-Jasso et al., 2012) (Fig. 4). These long events were not observed in the winter months, although the study of Mateos-Jasso et al. (2012) covers few years.

Before the arrival of a cold front, southeasterly winds are observed, associated with high moisture content, high temperatures and low atmospheric pressure. Once the front crosses a given location, the wind intensifies and changes its direction, the atmospheric pressure increases, and the temperature drops (DiMego et al., 1976). Frequently, during the frontal passage, heavy precipitation occurs (López-Méndez, 2009).

\section{Heat fluxes}

The SST of the GoM has a large amplitude annual cycle, with a considerable spatial variability. This was the object of study in the 1980s, 1990s, and early 2000s, but recently there has not been an update based on new available data and high resolution models. The goal of an update should be to have smaller uncertainties on the assessment of the contribution of each term in the heat balance equation (Eq. 1). Some early studies estimated the value of one or several terms of the heat content equation for the GoM (Hastenrath, 1968; Etter, 1983; Etter et al., 1987; Adem et al., 1993; Zavala-Hidalgo et al., 2002), which can be represented as follows: 

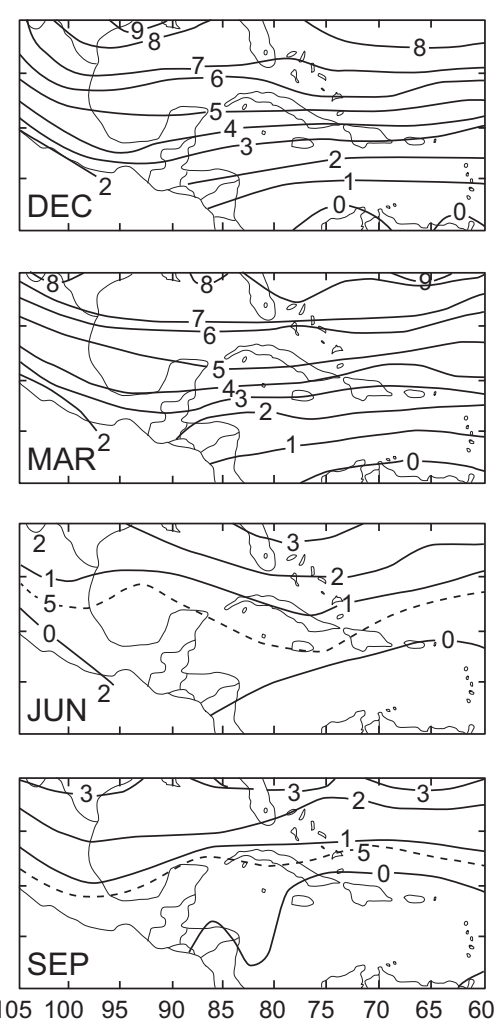
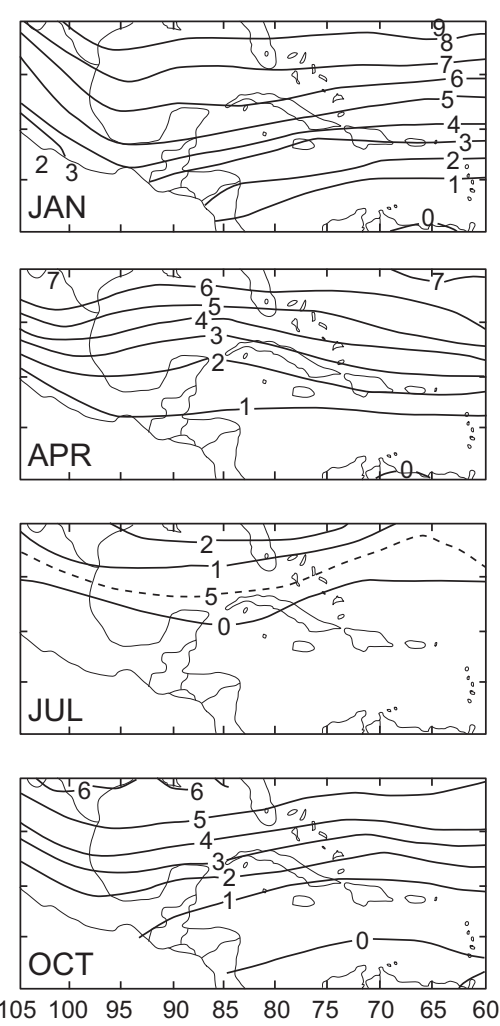
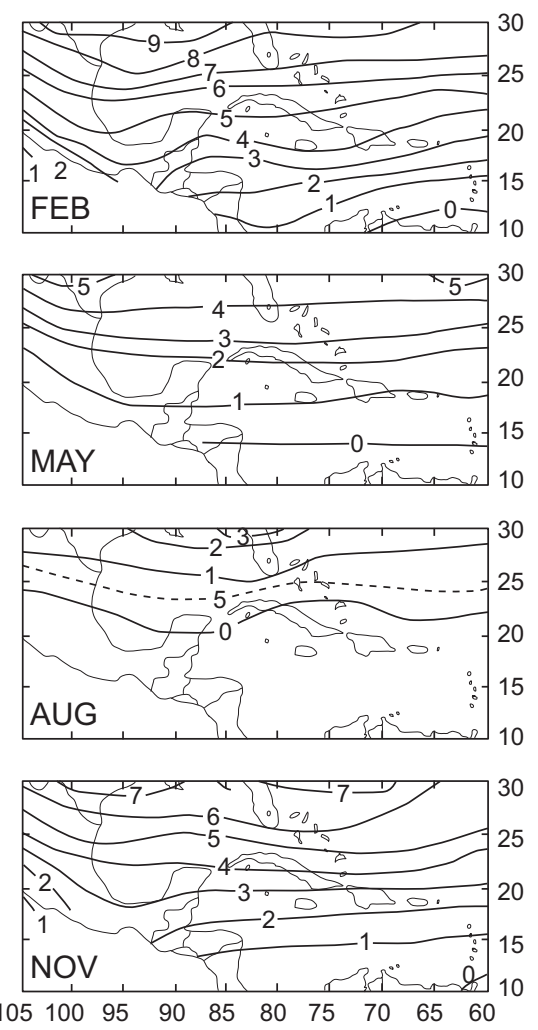

Fig. 3. Long-term monthly means of the frequency of occurrence of frontal systems during the 1965-1972 period. Figure from DiMego et al., 1976.

$\partial H / \partial t=Q_{s}+Q_{b}+Q_{e}+Q_{h}+Q_{a}$

where

$H=\int \rho C_{p}\left(T-T_{r e f}\right) d z$

is the total heat energy, $\rho$ is the density and $C_{p}$ is the specific heat of sea water, $T$ is the temperature, and $T_{\text {ref }}$ is a reference temperature so that $H$ values are relative to it. $Q_{s}, Q_{b}, Q_{e}$, and $Q_{h}$ are the net short wave radiation into the ocean, the heat emitted by the ocean as long wave radiation (including the atmospheric feedback due to the greenhouse effect), the latent heat flux due to evaporation, and the sensible heat, respectively (in this case all terms are positive when the ocean gains heat, so usually $Q_{b}$ is negative). The term $Q_{a}$ is the lateral heat advection. Heat content has been estimated based on hydrographic data (Etter, 1983), empirical formulae and, in some cases, considering the temperature and fluxes through the Yucatan Channel (Hastenrath, 1968; Hastenrath and Lamb, 1978; Etter, 1983; Adem et al., 1993). These estimations have shown that the GoM gains heat from March or April to August or September, with the peak of heat gain between May and July. The net surface heat flux over the whole year is estimated to vary between $-24 \mathrm{Wm}^{-2}$ and $46.6 \mathrm{Wm}^{-2}$ (Table I). Differences are due to the different methodologies used in those studies, e.g. different turbulent coefficients on the bulk formulae, short wave radiation formulations, cloud cover, wind speed, and the consideration or not of entrainment (see Zavala-Hidalgo et al., 2002 for a detailed discussion of each term). Heat fluxes associated with individual synoptic scale events, such as northers, may be very large, as discussed by Nowlin and Parker (1974), Villanueva et al. (2010), and Rudzin et al. (2013).

\section{Mixed layer depth and entrainment}

Zavala-Hidalgo et al. (2002), Mendoza et al. (2005), and Villanueva et al. (2010) proposed that the mixed layer entrainment via turbulent mixing has a significant contribution to the winter SST cooling. It was found that there is a better agreement between observations and the modeled SST when entrainment is considered. SST, mixed layer depth and entrain- 


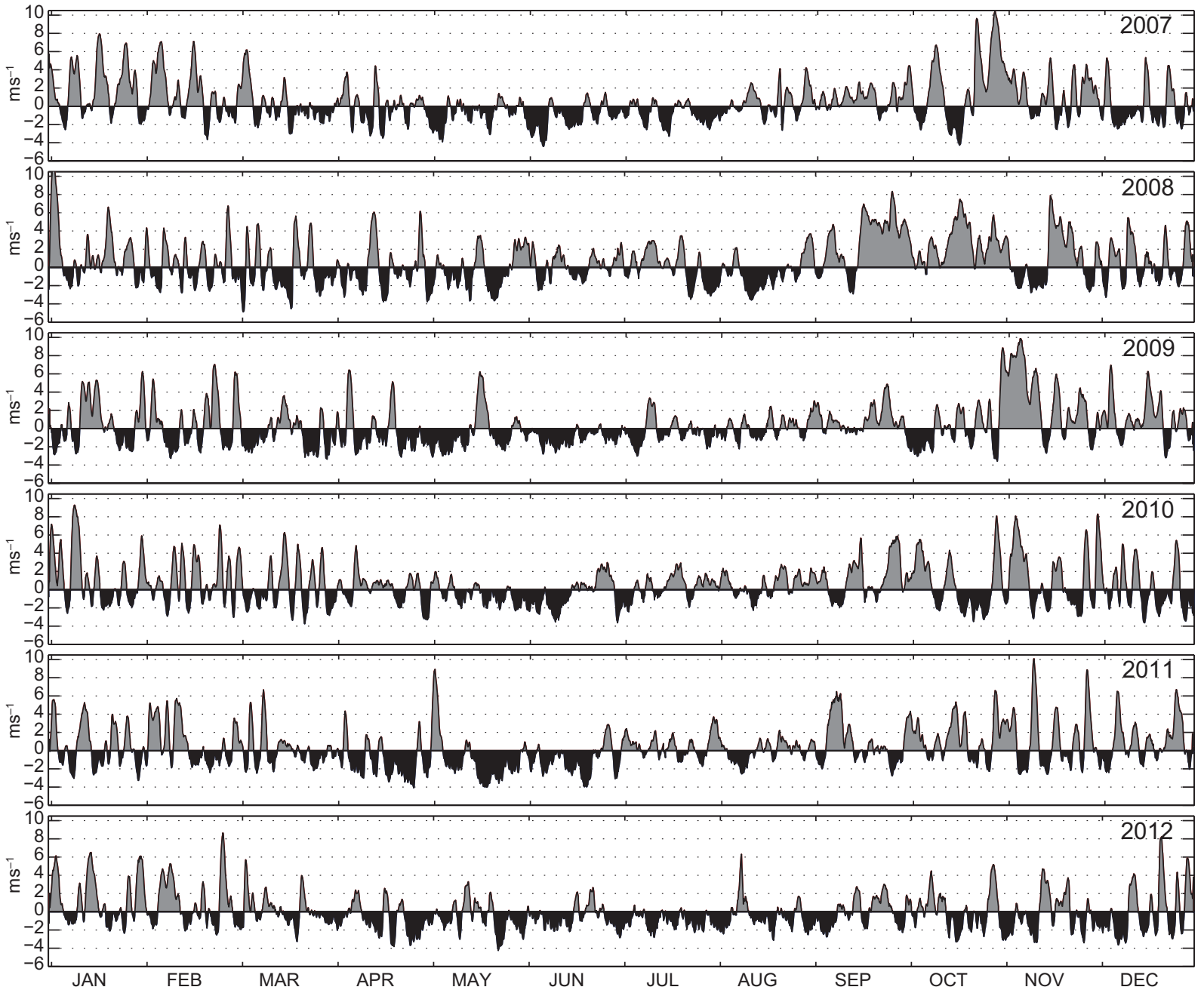

Fig. 4. Along-coast wind component at the Veracruz Coral Reef System computed from the NARR data (2007-2012): northwesterly winds in gray and southeasterly winds in black (following Mateos-Jasso et al., 2012).

Table I. Total average surface heat fluxes in $\mathrm{Wm}^{-2}$ from different studies. Sat \& EF are results from Zavala-Hidalgo et al. (2002) considering radiation measured by satellites and empirical formulas; BF are results from ZavalaHidalgo et al. (2002) considering bulk formulas; H68 are estimations by Hasternrath (1968); E83 are estimations by Etter (1983), and A93 are estimations by Adem et al. (1993). Table addapted from Zavala-Hidalgo et al. (2002).

\begin{tabular}{ccccrr}
\hline Month & Sat \& EF & BF & H68 & E83 & \multicolumn{1}{c}{ A93 } \\
\hline 1 & -69.5 & -43.9 & -64.4 & -137.0 & -105.0 \\
2 & -32.0 & -0.9 & -26.6 & -72.0 & -48.3 \\
3 & 12.1 & 55.9 & 19.8 & -11.0 & 8.3 \\
4 & 56.1 & 102.7 & 36.3 & 64.0 & 65.0 \\
5 & 84.1 & 135.5 & 52.3 & 84.0 & 76.7 \\
6 & 78.8 & 134.7 & 31.5 & 85.0 & 88.3 \\
7 & 80.8 & 129.9 & 36.8 & 72.0 & 100.0 \\
8 & 70.9 & 108.2 & 33.9 & 49.0 & 43.7 \\
9 & 17.2 & 54.5 & -0.5 & -23.0 & -12.7 \\
10 & -37.7 & -5.8 & -74.1 & -96.0 & -69.0 \\
11 & -69.5 & -45.3 & -107.4 & -149.0 & -81.0 \\
12 & -83.5 & -66.0 & -118.6 & -155.0 & -93.0 \\
Annual & 9.0 & 46.6 & -15.1 & -24.0 & -2.2 \\
\hline
\end{tabular}


ment were estimated using a primitive equation numerical model with bulk formulas by Zavala-Hidalgo et al. (2002), and using a model with climatological currents coupled to a Kraus-Turner type model (Kraus and Turner, 1967) by Mendoza et al. (2005). Both studies show similar annual cycles and values for the entrainment, with larger values between November and February, and for the mixed layer depth, which is deeper in December-March and shallower in June-August (Fig. 5). In addition, it was shown that there is a strong relation between the entrainment and pigment concentration in the deep GoM (estimation of chlorophyll-a concentration), with high values during winter and low in summer (Fig. 5).

The autumn-wintertime changes of mixed layer depth and entrainment discussed above are mainly due to the northers, through increased mixing and cooling heat flux during autumn-winter. These processes are more intense in the northern GoM where
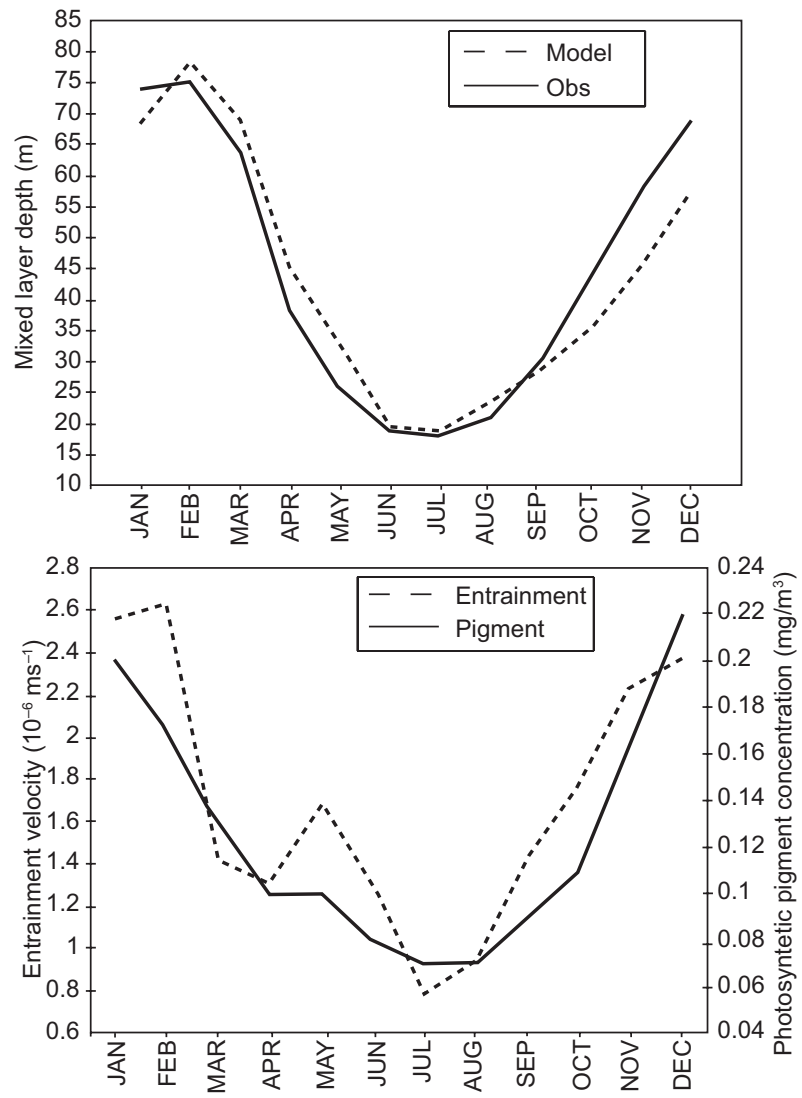

Fig. 5. Top: Comparison of the annual cycle of the mixed layer depth from observations (solid line) and model results (dashed line). Bottom: Annual cycle of the entrainment velocity (dashed line) and the photosyntetic pigment concentration (solid line). Adapted from Mendoza et al., 2005. the lowest temperatures are observed. The impact of a single norther on the SST and mixed layer depth was studied by Villanueva et al. (2010). During that event there was a larger contribution to the temperature decrease by the entrainment than by the added contribution of the sensible and latent heat fluxes.

\section{Shelf circulation}

There are differences between the physical processes in the deep ocean and those occurring on the shelves, even considering only the near surface layer of tens of meters. The shoreline restricts the motion leading to circulation patterns that are not observed in the open ocean, in particular the coastally trapped waves, mainly barotropic, although baroclinic waves are observed along the slope. Another difference is the influence on the dynamics of rivers discharge, which induces strong density gradients by the input of fresh water that affects the water motion through buoyancy forces. Another major characteristic of the shelf circulation is due to the relatively low depth, which makes the bottom friction important. In addition to those characteristics of the shelves, the slope works, in some cases, as a barrier between the deep ocean and the shelf because of the conservation of potential vorticity, making the ratio of along-shelf current variability to cross-shelf current variability large.

Several studies have shown that the dynamics of the shelves, particularly in the inner shelf of wide shelves, is mainly driven by the local momentum flux and the fresh river input. Over the outer shelf, deep ocean eddies and the Loop Current may have an important contribution when they impinge on the shelf slope (Oey, 1995; Walker, 2005; Weisberg et al., 2005; Dubranna et al., 2011). The wind stress forcing has a seasonality in its direction and intensity, reversing the inner shelf currents along the year. The shelves in the GoM are distinguished by their behavior along the annual cycle, that is the case of the West Florida Shelf (WFS), the Mobile-Alabama-Florida shelf(MAFLA), the Texas-Louisiana shelf(LATEX), the Tamaulipas-Veracruz shelf (TAVE), and the Campeche Bank. Most studies have found that the inner-shelf is dominated by a wind-driven circulation with the along-coast wind stress component determining the current direction (e.g. Zavala-Hidalgo et al., 2003; Nowlin et al., 2005; Weisberg et al., 2005). Therefore, a scheme showing the monthly along-coast wind stress component has been helpful 
to understand the seasonality of the currents and other processes (Morey et al., 2005; Zavala-Hidalgo et al., 2006) (Fig. 6). There are regions showing a different behavior of the along-coast wind stress component and its variability along the year. The Campeche Bank has a clockwise wind stress component during the whole year; a small region offshore of the Campeche State has weak wind stress but changes between a counterclockwise direction during spring-summer to a clockwise during autumn-winter. The southernmost part of the GoM, in front of the Tabasco State, also shows a clockwise direction along the year. The region between southern Veracruz to the international border at the Río Bravo (Río Grande) mouth has a counterclockwise along-coast wind stress direction between September and March and clockwise between April and August. In the LATEX shelf, most of the year the wind stress component is counterclockwise except for a small period when it reverses. The WFS has a period with clockwise along-coast winds between October and March, and counterclockwise between April and September.

The seasonal shift in the wind direction has an associated directional change in the momentum fluxes affecting mainly the inner-shelf, in particular when the along-coast wind stress component is large. Major results regarding the circulation on the shelves are presented next.

\subsection{The Texas-Louisiana shelf}

The circulation on the LATEX shelf has been studied intensively based on hydrographic surveys (Cochrane and Kelly, 1986), current meters, meteorological buoys (Cho et al., 1998; Nowlin et al., 1998a, b), and numerical modeling (Oey, 1995; Zhang and Hetland, 2012). The low frequency circulation on the LATEX shelf is dominated by a wind-driven cyclonic circulation, with a strong jet over the inner-shelf and a weaker and broader northeastward current over the outer shelf. This pattern is observed most of the year, except during July and August when the alongcoast wind component reverses (Cochrane and Kelly, 1986; Cho et al., 1998; Wang et al., 1998; Nowlin et al., 2005). Over the outer shelf and the shelf break, the circulation is predominantly clockwise, probably due to the impingement of decaying anticyclonic eddies on the shelf edge. During the non-summer period, the shelf shows mainly a counterclockwise (clockwise) circulation in regions where depth is shallower (deeper) than $50 \mathrm{~m}$. Variability on the inner-shelf is dominated by the 2- to 10-day time scale, consistent with synoptic scale atmospheric forcing, while in the outer shelf is on the oceanic mesoscale time scale (10-100 days), suggesting that the main forcing in the outer shelf is related with the impinging eddies on the shelf edge (Nowlin et al., 2005).

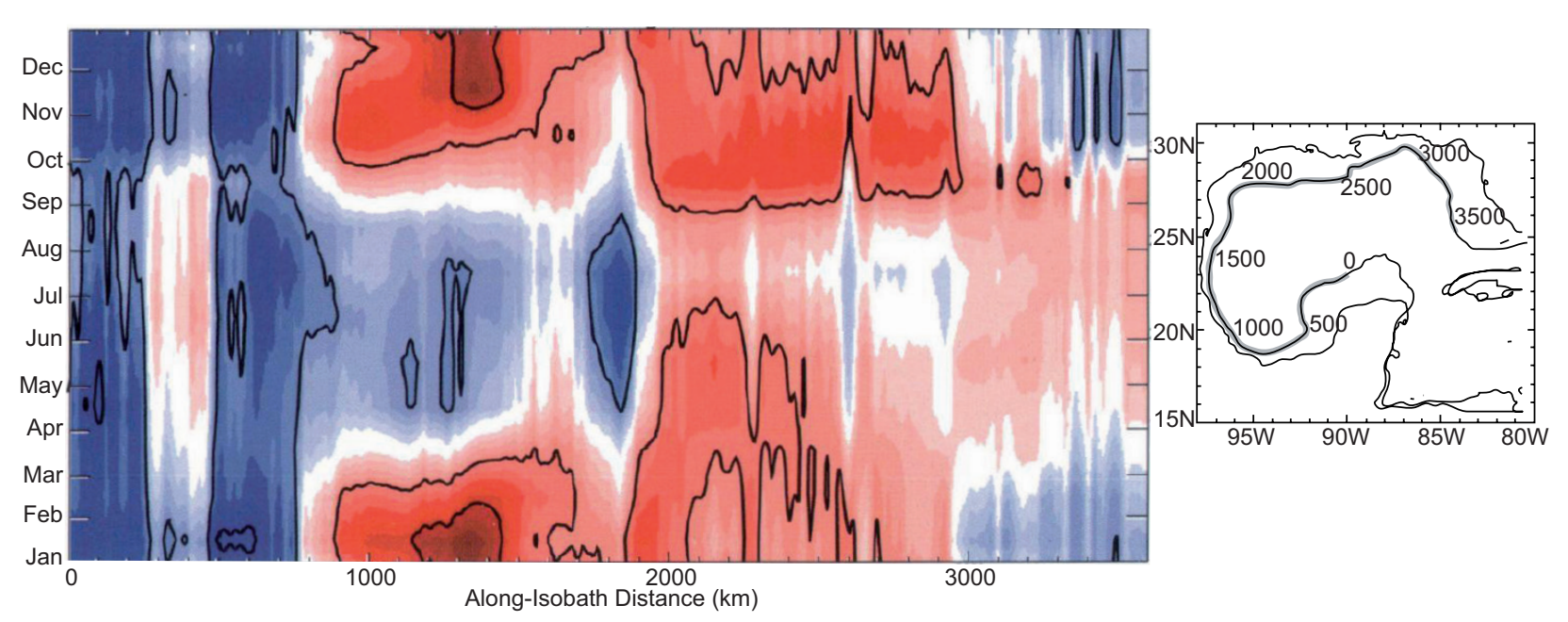

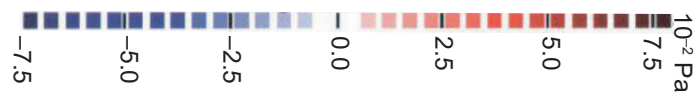

Fig. 6. Monthly climatology of the wind stress $\left(\times 10^{-2} \mathrm{~Pa}\right)$ along the $200 \mathrm{~m}$ isobath. The corresponding locations for along-isobath distances in the left panel are indicated in the map. Positive in the counterclockwise direction (from Morey et al., 2005). 


\subsection{The Tamaulipas-Veracruz shelf}

Compared to the LATEX shelf, there have been few studies on the TAVE shelf and observations are scarce. The most extensive observational program in the area has been the Canek Project, carried out by the Centro de Investigación Científica y de Educación Superior de Ensenada (Dubranna et al., 2011; Pérez-Brunius et al., 2013). Other observations have been made on the TAVE shelf at the regional level (Mateos-Jasso et al., 2012). Also, numerical studies have given a general view of the low frequency characteristics of the circulation on this shelf (Zavala-Hidalgo et al., 2003; Morey et al., 2005).

A major difference between the TAVE and the LATEX shelves is that the TAVE is narrower, varying from around $65 \mathrm{~km}$ width in the border between Tamaulipas and Texas to around $15 \mathrm{~km}$ in southern Veracruz and $40 \mathrm{~km}$ in Tabasco, compared to the $200 \mathrm{~km}$ width of the LATEX shelf. This difference affects the circulation because a distinction between the inner and outer shelves in the TAVE shelf is not as clear as in the LATEX shelf. The impinging eddies on the slope affect the external or outer shelf and studies on the LATEX shelf found that they have a major influence in the circulation from the shelf edge to the $50 \mathrm{~m}$ isobath, but a similar study has not been done in the TAVE shelf.

Boicourt et al. (1998) first suggested that there may be a reversal of the currents on the TAVE shelf. Based on a numerical study, Zavala-Hidalgo et al. (2003) found a seasonal shift in the inner-shelf circulation (from the coast to the $25 \mathrm{~m}$ isobath) along the TAVE shelf, being clockwise between May and August and counterclockwise between September and March. They were also able to reproduce the previously reported circulation for the LATEX shelf, being downcoast during the non-summer months and upcoast in July. They computed the transports between the $25 \mathrm{~m}$ and the $50 \mathrm{~m}$ isobaths on the TAVE shelf and obtained similar directions than those for the inner shelf. However, the TAVE shelf is narrow and more observations are needed to identify the coherence of the circulation between the inner and outer shelf.

During the Canek project, seven moorings were installed along the TAVE shelf and the southern GoM at $130 \mathrm{~m}$ depth from November 2007 to July 2009. On the monthly scale, correlations between the along-shore wind stress and the along-shelf currents of about 0.77 and 0.78 on northern Veracruz and southern Tamaulipas, were estimated. Significant correlations of 0.47 in southern Veracruz (offshore of Coatzacoalcos) and of 0.41 in a site northwest of Ciudad del Carmen, Campeche, were found. However, a low and non-significant correlation was found offshore of Alvarado, Veracruz. Observed currents on the shelf of Veracruz in summer, pointing upcoast (clockwise), were about 15 to $40 \mathrm{~cm} \mathrm{~s}^{-1}$. In northern Veracruz and central Tamaulipas current velocities in winter were 30 to $40 \mathrm{~cm} \mathrm{~s}^{-1}$. It was also observed that in Tamaulipas there was a period in January when the current was heading northward while the wind was downcoast. Finally, a non-significant correlation between the along coast wind-stress and the observed currents offshore of northern Tamaulipas (Perdido) was found, although on average the seasonal pattern, with prevailing northward currents in spring-summer and southward currents in autumn-winter, was observed. During that project, the trajectory of drifters reaching the continental shelf was analyzed, concluding that during spring-summer $70 \%$ of the time the drifters headed upcoast. However, they found that there were some differences between drifters north of $21^{\circ} \mathrm{N}$, which all headed north, and those south of that latitude, which had more variable trajectories. During fall and winter, $74 \%$ of the drifters headed downcoast.

Coastally trapped waves were identified on the TAVE shelf by Dubranna et al. (2011) in the current observations associated to the intrusion of cold fronts with intense along-shore downcoast winds (Fig. 7). They identified two events in September and two in October. The phase speed of the coastal waves was estimated at $2.9 \mathrm{~ms}^{-1}$, which was corroborated with the increase of the sea level in Veracruz city in both episodes.

\subsection{The West Florida Shelf}

The dynamics of the West Florida Shelf (WFS) are dependent on deep ocean forcing, as well as local and remote atmospheric forcing over the shelf. It is a complex wide continental shelf delimited to the south by the Florida Keys to the Dry Tortugas. The WFS is almost closed at its southern end since fluxes across the Florida Keys are very small. On the western side it interacts with the Loop Current across the shelf break. The shelf isobaths curve westward nearly $90^{\circ}$ over the "Big Bend" region of Florida, and then converge 


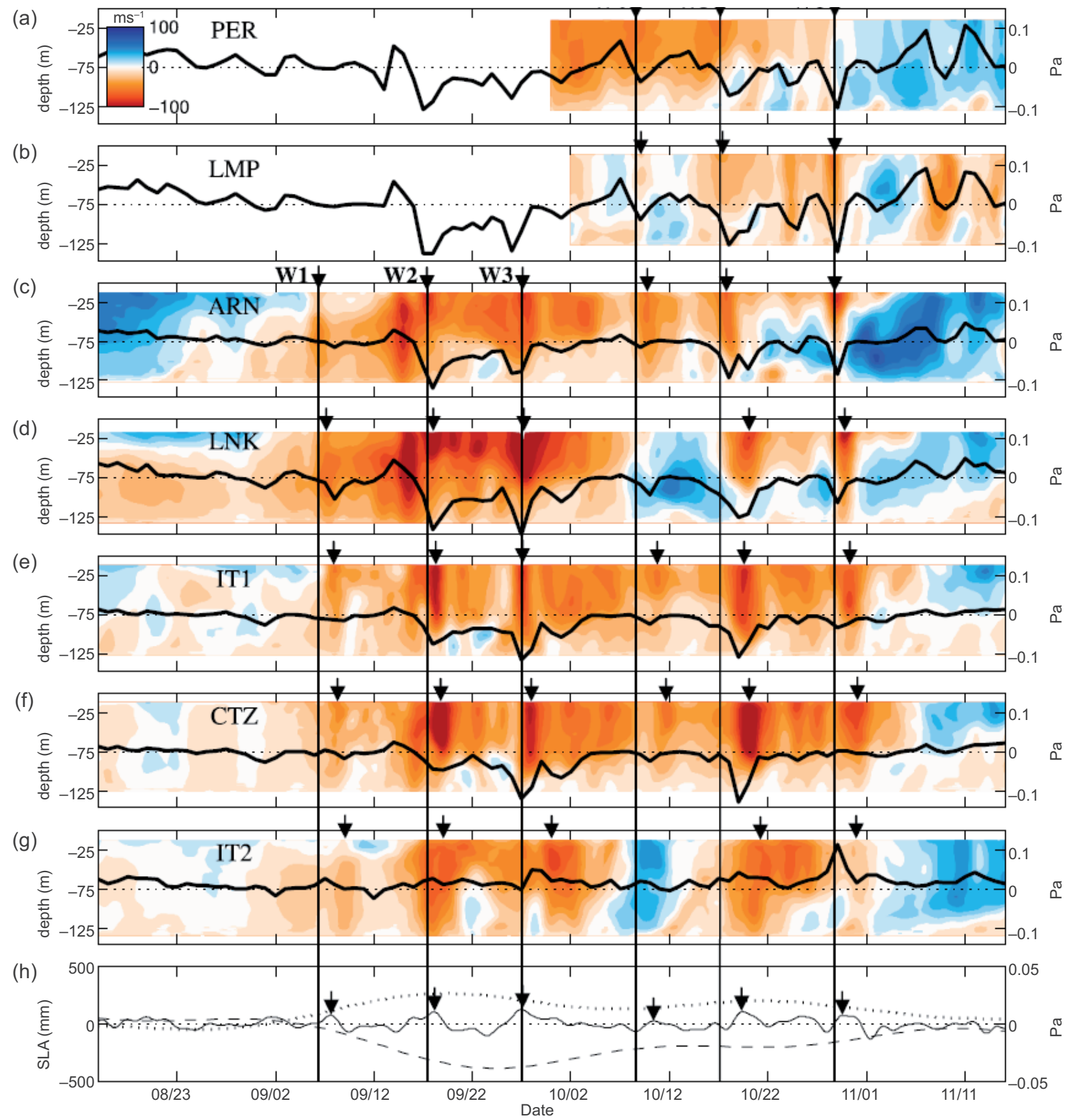

Fig. 7. Alongshore current velocities $\left(\mathrm{cm} \mathrm{s}^{-1}\right)$ measured by the moorings: (a) PER, (b) LMP, (c) ARN, (d) LNK, (e) IT1, (f) CTZ, and (g) IT2 (see Fig. 1 for location). Superimposed are the alongshore wind stresses at the position of the moorings. Positive (negative) values are upcoast (downcoast). The beginning of events of interest is marked by a vertical solid line with a W. Arrows show the maximum mean current speed following each W event. (h) The lowpassed (cutoff period is 30 days, dotted line) and band-passed (periods between 2 and 30 days, solid line) sea level anomaly (SLA) at the City of Veracruz which is located between LNK and IT1. SLA corresponding to the W events are marked by an arrow.

as the shelf narrows to join the northwest Florida Panhandle shelf inshore of DeSoto Canyon. The DeSoto Canyon is an area with a narrow steep shelf, potentially allowing more interaction of the inner shelf with the deep gulf. The WFS has been largely studied by long-term mooring observations and models (He and Weisberg, 2002, 2003; Weisberg and He, 2003; Liu and Weisberg, 2005; Weisberg et al., 2005; 
Maksimova and Clarke, 2013). On average, the WFS has southeastward (northwestward) circulation on the inner shelf and upwelling (downwelling) favorable conditions during autumn-winter (summer). The inner-shelf circulation is decoupled from the middle and outer shelf circulation since frequently they have different direction (Liu and Weisberg, 2005). The explanation for this difference is a return flow that develops because the Florida Keys are a barrier to the flow, thus when there is a southeastward flow in the inner shelf, it reaches the Keys and a return flow develops. Mixing and surface heat fluxes also affect the dynamics because the inner shelf increases (decreases) its temperature faster than the intermediate shelf in the spring (autumn), developing cross-shelf pressure gradients that reinforce the circulation differences between the inner and intermediate shelf. The Loop Current interacts with the slope and develops pressure gradients that affect the shelf circulation.

\subsection{The Campeche Bank}

The Campeche Bank includes the broad shelf to the north and the narrower shelf to the northwest of the Yucatan Peninsula. There have been few observational studies on the hydrodynamics of the Campeche Bank, most of them based on hydrographic data (e.g. Cochrane, 1969; Merino, 1997). The winds over the Campeche Bank are upcoast, with an eastward component, throughout the year, and are more intense in April-June and weaker in September-October (Enríquez et al., 2010). The currents are mainly westward, fed by the Yucatan Current waters (for the Yucatan Current see for example Ochoa et al., 2001; Sheinbaum et al., 2002). Zavala-Hidalgo et al. (2003), based on a numerical study, reports that on a monthly scale the transports north of the Yucatan state are upcoast year round in the inner and middle shelf. In the western Campeche Bank, transports on the inner shelf are upcoast and on the middle shelf the transports are also upcoast but they decrease during October. Results from Sanvicente-Añorve et al. (2014) suggest that, over the outer shelf of the western Campeche Bank, the current is downcoast during September and October and the rest of the year has variable direction. The need for observational studies in the Campeche Bank region is quite evident from the literature review.

\section{Cross-shelf transports}

As mentioned above, cross-shelf transports are constrained by the conservation of potential vorticity, such that the barotropic circulation is dominantly in the along-isobath direction. Therefore, cross-shelf transports imply that either there is strong baroclinicity, or friction and other terms are important in the momentum balance equation, making these motions less frequent than along-shelf motions. On the other hand, cross-shelf motions are important because they may carry nutrient rich subsurface water onto the shelf, and the shelf may bring riverine low salinity waters into the deep ocean. Also, cross-shelf transports may carry contaminants coming from inland into the deep ocean, or from the deep ocean onto the shelf as happens when there are deep ocean oil-spills. Larvae are also transported from the shelf to the deep ocean or vice versa (Sanvicente-Añorve et al., 2014).

In the GoM, eddy-pairs have been associated with cross-shelf transports (Biggs and Müller-Karger, 1994), but it has been demonstrated that there are regions with some seasonality in the cross-shelf transports not always related to eddy-pairs. The following summarizes those results.

Spatial variability of wind-driven circulation on the shelves results in differences in along-shelf transport, which in turn lead to regions of convergence or divergence. As seen in previous sections, this may be caused by the corresponding convergence or divergence of the along-coast wind component, which can occur due to spatial variability of the wind field or changes in orientation of the shelf under a relatively homogeneous wind field. The low frequency along-coast wind component has a region of convergence in the southernmost part of the GoM, mainly from September to February although present throughout the year; in the southern Texas shelf there is convergence between April and August. These two regions were identified to have large seasonality in their associated values of chlorophyll-a concentration and low salinity waters (Morey et al., 2003a, b, 2005; Zavala-Hidalgo et al., 2003; Martínez-López and Zavala-Hidalgo, 2009). In addition to these regions, a low salinity and high chlorophyll-a concentration seasonal signature has been identified offshore of the Mississippi river (Fig. 8), with a peak in June-August due to the southerly winds in the region favoring a westward Ekman transport during these months. Martínez-López and 


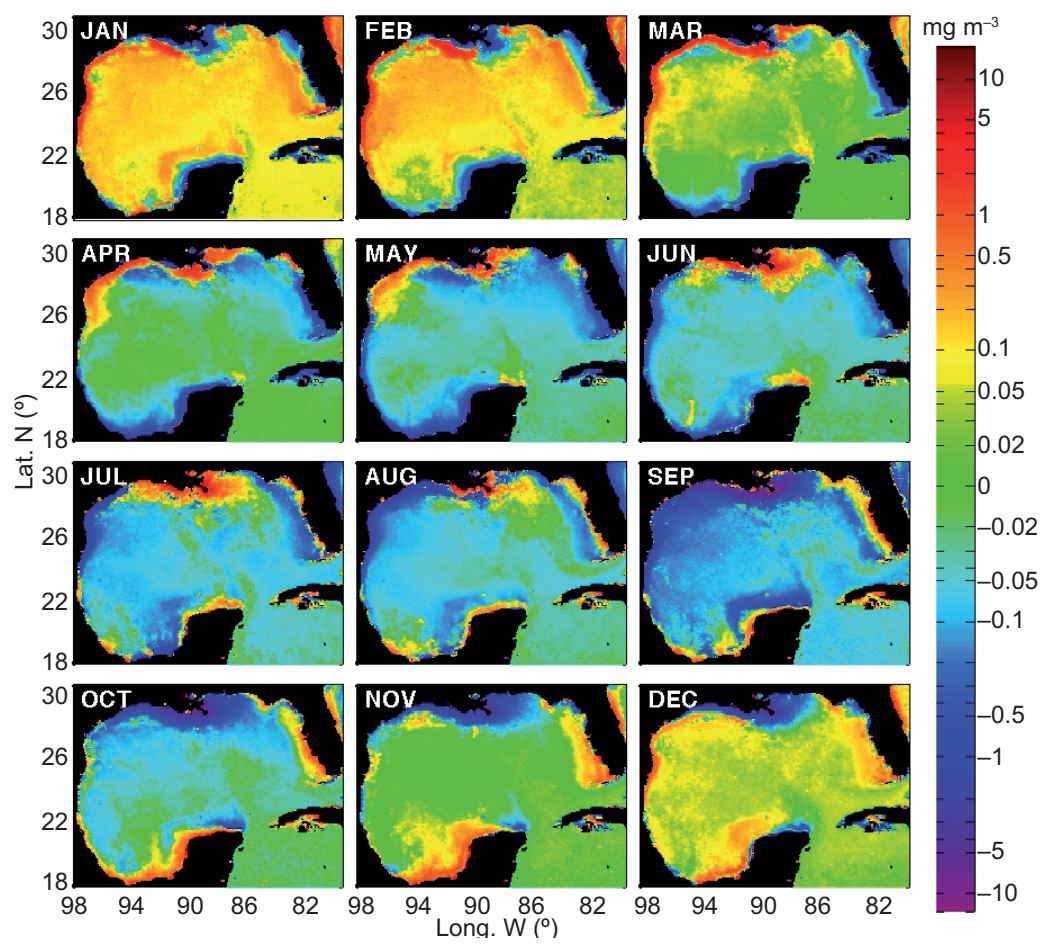

Fig. 8. Long-term monthly means (1997-2012) of chlorophyll-a concentration anomalies in the Gulf of Mexico. Anomalies were computed relative to the annual mean following the Martínez-López and Zavala-Hidalgo (2009) method.

Zavala-Hidalgo (2009) showed that the interannual variability of the chlorophyll-a concentration offshore of the southern Texas shelf and in the Bay of Campeche might be explained by the interannual variability of the along-coast wind stress component and the corresponding of the shelf currents. Here, we extend the period of their computations and found that high correlations remain, explaining a large fraction of the interannual variability of chlorophyll-a concentration by the convergence of mass induced by the along-coast currents in those regions (Fig. 9). The chlorophyll-a concentration values over the southern Bay of Campeche were averaged in a box located between $19.5^{\circ} \mathrm{N}$ and 20.5 $\mathrm{N}$ in latitude and $93^{\circ} \mathrm{W}$ and $92^{\circ} \mathrm{W}$ in longitude. For the southern Texas shelf, the box limits were $26.5^{\circ}$ $\mathrm{N}$ to $27.5^{\circ} \mathrm{N}$ in latitude and $96.75^{\circ} \mathrm{W}$ to $96^{\circ} \mathrm{W}$ in longitude.

\section{Upwelling}

Coastal upwelling has strong seasonality in the GoM, but occurs at different periods over different shelves. The TAVE shelf, in the western GoM, has upwelling conditions predominantly during summer, as has been identified in satellite images (Walker et al., 2003; Walker, 2005; Zavala-Hidalgo et al., 2006) (Fig. 10). The analysis in Mateos-Jasso et al. (2012), based on long-term almost continuous measurements of temperature in the water column at the Sistema Arrecifal Veracruzano (SAV), offshore of Veracruz city, shows stratification between April and September with low temperature near the bottom due to upwelling in the region. The upwelling is interrupted by the influence of tropical systems, like easterly waves and tropical storms, which change the Ekman transport from upwelling to downwelling conditions increasing temperature of the entire water column (Fig. 11). The signature of the upwelled water in the SST is relatively weak because the outcropping of the isotherms is not often observed in the satellite images. Upwelling and downwelling over the WFS occur in almost opposite seasons than in the TAVE shelf, with upwelling occurring in winter and downwelling in summer (Weisberg et al., 2005). There are important differences between the upwelling in the WFS and the TAVE shelves, since northerly winds in winter 
a

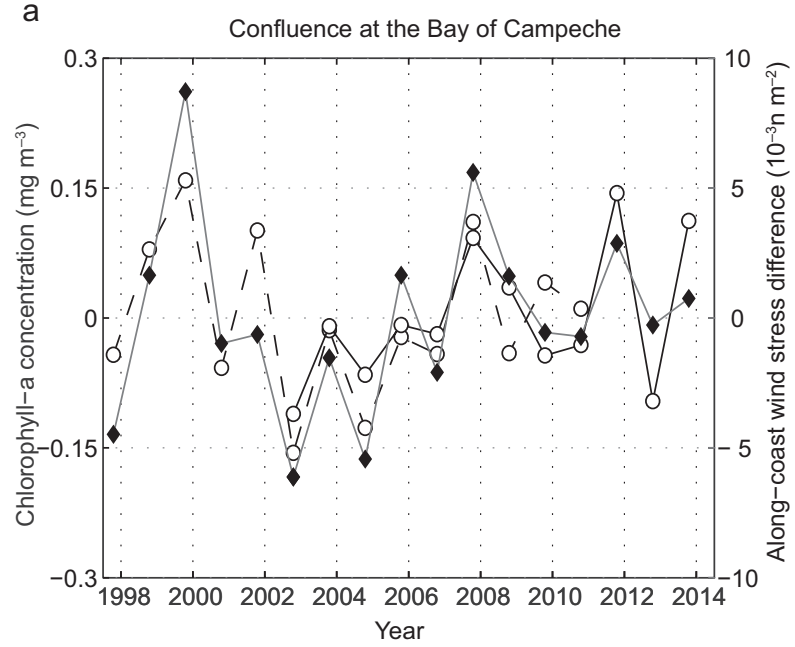

b

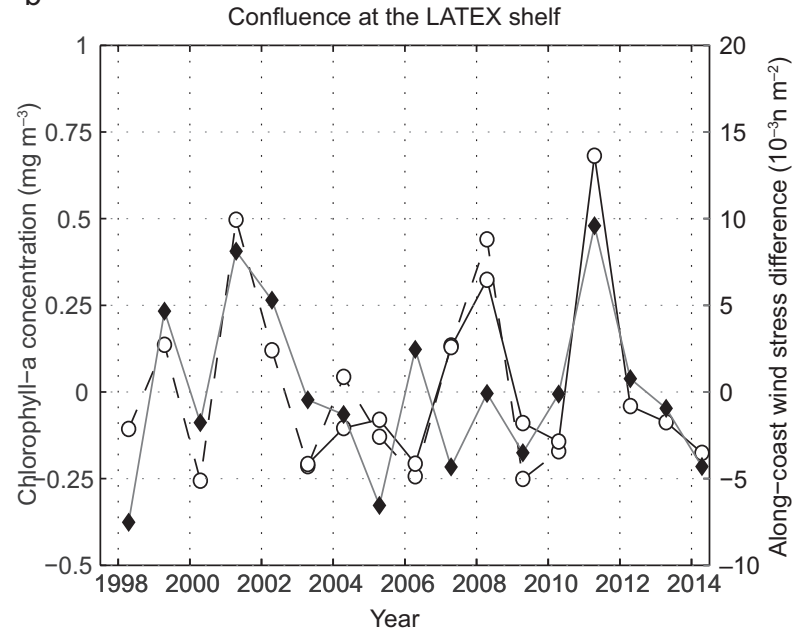

Fig. 9. Alongshelf wind convergence anomalies (graythick line) and chlorophyll-a concentration anomalies from both SeaWiFS data (dashed line) and MODIS data (solid line). Upper panel: October-November anomalies in the Bay of Campeche. Lower panel: April-June anomalies in the southern Texas shelf. Following computations from Martínez-López and Zavala-Hidalgo (2009).

that induce upwelling (downwelling) in the WFS (TAVE) are more intense than the southeasterlies in summer that induce downwelling (upwelling) in the WFS (TAVE).

\section{Discussion and final remarks}

The surface momentum and heat fluxes are intense in the GoM and are important for its hydrodynamics. As a consequence of these fluxes the mixed layer depth changes seasonally, being deeper in winter and there is a contribution on the winter cooling due to the entrainment of subsurface low temperature

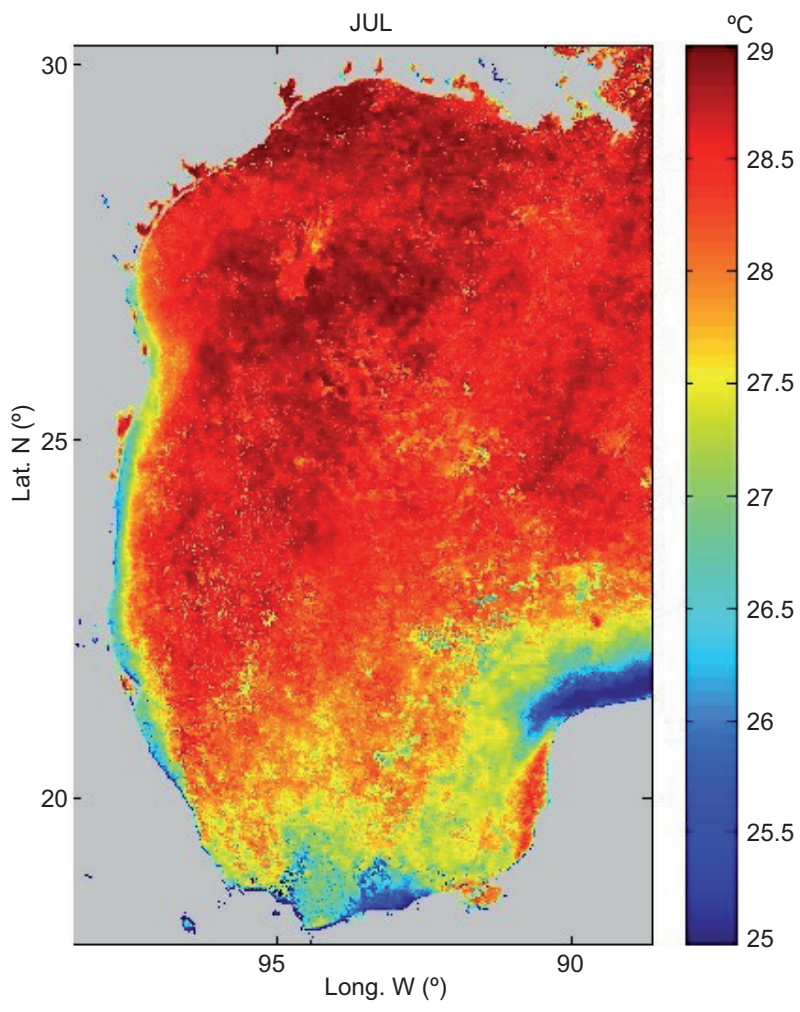

Fig. 10. Mean sea surface temperature in the Gulf of Mexico for July computed from an 8-year AVHRR database (adapted from Zavala-Hidalgo et al., 2006).

water that reaches the mixed layer. The entrainment also carries nutrients into the upper layer, increasing the chlorophyll-a concentration during winter months. Research on the importance of local forcing in the GoM has shown that shelves respond to wind stress and buoyancy fluxes due to surface heat fluxes and fresh water inputs. The response to the local forcing is more clear or, in some cases, limited to the inner shelf that develops along-shore currents as a consequence of the surface Ekman transport that induces cross-shelf pressure gradients and geostrophic along-coast currents. The heat fluxes also can induce cross-shelf pressure gradients because temperature decreases (increases) faster in autumn (spring) in the shallower regions, as has been shown for the WFS. The wide shelves, as the LATEX, the WFS and the Campeche Bank, have a well defined inner shelf strongly influenced by the along-coast wind stress. The external shelf has the influence of the Loop Current and the Loop Current eddies through their interaction with the slope, but still there are many open questions on these processes. 


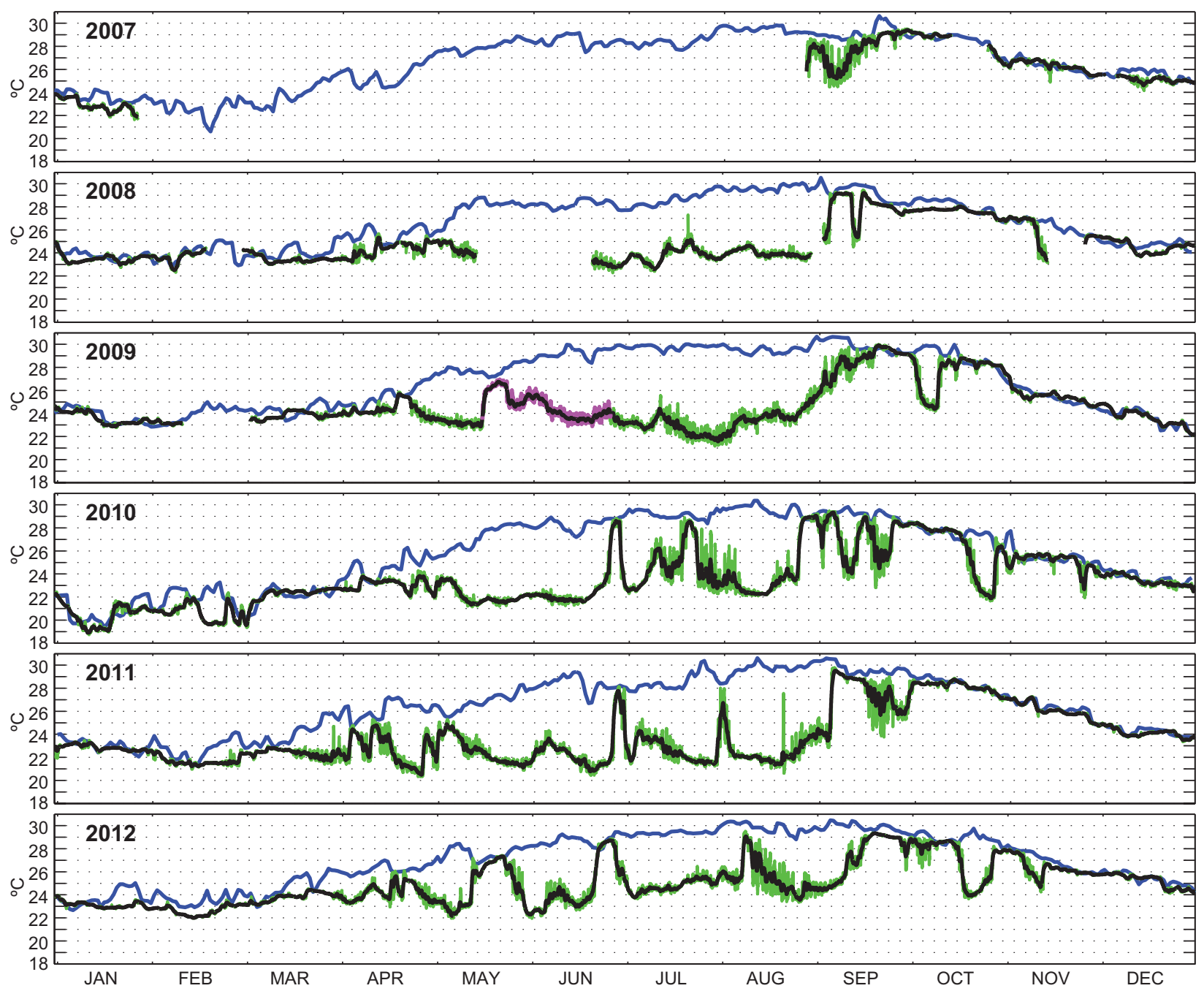

Fig. 11. Annual time series of temperature at the surface and bottom $(30 \mathrm{~m})$ in the northern Veracruz Coral Reef System for the years 2007-2012. SSTs from the AVHRR (blue); bottom temperature from an ADCP recorded every 30 min (green), and temperature measured by a moored thermistor at $27 \mathrm{~m}$ (purple). Black line represents the 24-h running mean (following Mateos-Jasso et al., 2012).

In the Bay of Campeche and offshore of the southern LATEX shelf, seasonality has been identified in cross-shelf transports as a result of the influence of the along-shelf wind stress component. This behavior has also been observed by the seasonality of the chlorophyll-a concentration estimated from satellites in those regions and by the modeled offshore export of low salinity waters. Also, the seasonality of the chlorophyll-a concentration, offshore of the Mississippi river mouth, was reported and explained as a consequence of the seasonality of the wind stress direction, which favors a westward transport in the northern GoM during summer.

\section{Acknowledgements}

We thank Octavio Gómez-Ramos for his help with the computer systems. To Ángel RuizAngulo and an anonymous reviewer for their valuable suggestions that improved the manuscript. This work was supported by grants PAPIIT IN116111, PAPIIT RR116111, and CONACyT 133299. Steven L. Morey was supported by a grant from the BP/Gulf of Mexico Research Initiative to the Deep-C Consortium and by a NASA grant as part of the Ocean Vector Winds Science Team.

\section{References}

Adem J., E. E. Villanueva-Urrutia and V. M. Mendoza, 1993. A new method for estimating the seasonal cycle 
of the heat balance, with application to the Gulf of Mexico. Geofis. Int. 32, 21-34.

Biggs D. C. and F. E. Müller-Karger, 1994. Ship and satellite observations of chlorophyll stocks in interacting cyclone-anticyclone eddy pairs in the western Gulf of Mexico. J. Geophys. Res. 99, 7371-7384.

Boicourt W. C., W. J. Wiseman Jr., Valle-A. Levinson and L. P. Atkinson, 1998. Continental shelf of the southeastern United States and the Gulf of Mexico: In the shadow of the western boundary current. In: The sea, vol. 11 (A. R. Robinson and K. H. Brink, Eds.). John Wiley, Hoboken, N. J., pp. 135-182.

Burphee W. R., 1974. Characteristics of north african easterly waves during the summers of 1968 and 1969. J. Atmos. Sci. 31, 1556-1570.

Capurro L. R. A. and J. L. Reid (Eds.), 1972. Contributions on the physical oceanography of the Gulf of Mexico, vol. II. Gulf Publishing, Houston, Texas, 288 pp.

Cho K., R. O. Reid and W. D. Nowlin Jr., 1998. Objectively mapped stream function fields on the Texas-Louisiana shelf based on 32 months of moored current meter data. J. Geophys. Res. 103, 10377-10390.

Cochrane J. D., 1969. Water and circulation on Campeche Bank in May. Papers in Dedication to Professor Michitaka Uda. Special Bulletin of the Japanese Society of Fisheries Oceanography, 123-129.

Cochrane J. D. and F. J. Kelly, 1986. Low-frequency circulation on the Texas- Louisiana continental shelf. $J$. Geophys. Res. 91, 10645-10659.

Diedhiou A., S. Janicot, A. Viltard, P. de Felice and H. Laurent, 1999. Easterly wave regimes and associated convection over West Africa and tropical Atlantic: Results from the NCEP/NCAR and ECMWF reanalyses. Clim. Dynam. 15, 795-822

DiMego G. J., L. F. Nosart and G. W. Endersen, 1976. An examination of the frequency and mean conditions surrounding frontal incursions into the Gulf of Mexico and Caribbean Sea. Mon. Weather Rev. 104, 709-718.

Dubranna J., P. Pérez-Brunius, M. López and J. Candela, 2011. Circulation over the continental shelf of the western and southwestern Gulf of Mexico. J. Geophys. Res. 116, doi:10.1029/2011JC007007.

Enríquez C., I. J. Marinño-Tapia and J. A. Herrera-Siveira, 2010. Dispersion in the Yucatan coastal zone: Implications for red tide events. Cont. Shelf Res. 30, 127-137.

Etter P. C., 1983. Heat and fresh water budgets in the Gulf of Mexico. J. Phys. Oceanogr. 3, 2058-2069.

Etter P. C., P. J. Lamb and D. H. Portis, 1987. Heat and fresh water budgets in the Caribbean Sea with revised estimates for the Central American Seas. J. Phys. Oceanogr. 7, 232-1248.

Galtsoff P. S., 1954. Gulf of Mexico: Its origin, waters, and marine life. In: Fishery Bulletin, vol. 89. U.S. Fish and Wildlife Service.

Gutiérrez de Velasco G. and C. Winant, 1996. Seasonal patterns of wind stress and wind stress curl over the Gulf of Mexico. J. Geophys. Res. 101, 18127-18140.

Hastenrath S. L., 1968. Estimates of latent and sensible heat flux for the Caribbean and the Gulf of Mexico. Limnol. Oceanogr. 3, 322-331.

Hastenrath S. L. and P. Lamb, 1968. Heat budget atlas of the tropical Atlantic and eastern Pacific Oceans. University of Wisconsin Press, Madison, $90 \mathrm{pp}$.

He R. and R. H. Weisberg, 2002. West Florida shelf circulation and temperature budget for the 1999 spring transition. Cont. Shelf Res. 22, 719-748.

He R. and R. H. Weisberg, 2003. A loop current intrusion case study on the West Florida Shelf. J. Phys. Oceanogr. 33, 465-477.

Kraus E. B. and J. S. Turner, 1967. A one-dimensional model of the seasonal thermocline. II. The general theory and its consequences. Tellus 19, 98-106.

Liu Y. and R. H. Weisberg, 2005. Momentum balance diagnoses for the West Florida Shelf. Cont. Shelf Res. 25, 2054-2074.

Liu Y., A. MacFadyen, Z.-G. Ji and R. H. Weisberg (Eds.), 2011. Monitoring and modeling the deepwater horizon oil spill: A record-breaking enterprise. American Geophysical Union, Washington, DC, doi: 10.1029/ GM195, 271 pp. (Geoph. Monog. Series, 195).

López-Méndez J. V., 2009. Análisis del evento meteorológico relacionado con la inundación de Tabasco del 2007. M.Sc. Thesis, Posgrado en Ciencias de la Tierra, Universidad Nacional Autónoma de México, $117 \mathrm{pp}$.

Maksimova E. V. and A. J. Clarke, 2013. Multiyear subinertial and seasonal Eulerian current observations near the Florida Big Bend Coast. J. Phys. Oceanogr. 43,1691-1709.

Martínez-López B. and J. Zavala-Hidalgo, 2009. Seasonal and interannual variability of cross-shelf transports of chlorophyll in the Gulf of Mexico. J. Marine Syst. 77, 1-20.

Mateos-Jasso A., J. Zavala-Hidalgo, R. Romero-Centeno and M. E. Allende-Arandía, 2012. Variability of the thermohaline structure in the northern Veracruz coral reef system, Mexico. Cont. Shelf Res. 50-51, 30-40. 
Mendoza M., E. E. Villanueva and J. Adem, 2005. On the annual cycle of the sea surface temperature and the mixed layer depth in the Gulf of México. Atmósfera 18, 127-148.

Merino M., 1997. Upwelling on the Yucatan shelf: Hydrographic evidence. J. Mar. Syst. 13, 101-121.

Morey S. L., P. J. Martin, J. J. O’Brien, A. A. Wallcraft and J. Zavala-Hidalgo, 2003a. Export pathways for river discharged fresh water in the northern Gulf of Mexico. J. Geophys. Res. 108, doi:10.1029/2002JC001674.

Morey S. L., W. Schroeder, J. J. O’Brien and J. Zavala-Hidalgo, 2003b. The annual riverine influence in the eastern Gulf of Mexico. Geophys. Res. Lett. 30, 1867, doi:10.1029/2003GL017348.

Morey S. L., J. Zavala-Hidalgo and J. J. O’Brien, 2005. The seasonal variability of continental shelf circulation in the northern and western Gulf of Mexico from a high-resolution numerical model. In: Circulation in the Gulf of Mexico, observations and models (W. Sturges, Ed.). American Geophysical Union, Washington, DC, doi: 10.1029/161GM01, pp. 203-218 (Geoph. Monog. Series, 161).

Nowlin W. D., Jr. and C. A. Parker, 1974. Effects of a cold-air outbreak on shelf waters of the Gulf of Mexico. J. Phys. Oceanogr. 4, 467-486 .

Nowlin W. D., Jr., A. E. Jochens, R. O. Reid and S. F. DiMarco, 1998a. Texas-Louisiana shelf circulation and transport processes study: Synthesis report. Volume I: Technical report. OCS Study MMS98-0035. U.S. Department of the Interior, Minerals Management Service, Gulf of Mexico OCS Region, New Orleans, Louisiana, $502 \mathrm{pp}$.

Nowlin W. D. Jr., A. E. Jochens, R. O. Reid and S. F. DiMarco, 1998b. Texas-Louisiana shelf circulation and transport processes study: Synthesis report. Volume II: Appendices. OCS Study MMS-98-0036. U.S. Department of the Interior, Minerals Management Service, Gulf of Mexico OCS Region, New Orleans, Louisiana, $288 \mathrm{pp}$.

Nowlin W. D. Jr., A. E. Jochens, S. F. DiMarco, R. O. Reid and M. K. Howard, 2005. Low-frequency circulation over the Texas-Louisiana continental shelf. In: Circulation in the Gulf of Mexico, observations and models (W. Sturges, Ed.). American Geophysical Union, Washington, DC, doi: 10.1029/161GM01, pp. 219-240 (Geoph. Monog. Series, 161).

Ochoa J., J. Sheinbaum, A. Badan, J. Candela and D. Wilson, 2001. Geostrophy via 343 potential vorticity inversion in the Yucatan Channel. J. Mar. Res. 59, 725-747.
Oey L.-Y, 1995. Eddy and wind-forced shelf circulation. J. Geophys. Res. 100, 8621-8637.

Pérez-Brunius P., P. García-Carrillo, J. Dubranna, J. Sheinbaum and J. Candela, 2012. Direct observations of the upper layer circulation in the southern Gulf of Mexico. Deep-Sea Res. 85, 82-94, doi.org/10.1016/j. dsr2.2012.07.020

Romero-Centeno R., J. Zavala-Hidalgo, A. Gallegos and J. J. O'Brien, 2003. Isthmus of Tehuantepec wind climatology and ENSO signal. J. Climate 16, 2628-2639.

Rudzin J. E., S. L. Morey, M. A. Bourassa and S. R. Smith, 2013. The influence of Loop Current position on winter sea surface temperatures in the Florida Straits. Earth Interact. 17, doi: 10.1175/2013EI000521.1.

Sanvicente-Añorve L., J. Zavala-Hidalgo, M. E. Allende-Arandía and M. Hermoso-Salazar, 2014. Connectivity patterns among coral reef systems in the southern Gulf of Mexico. Mar. Ecol. Prog. Ser. 498, 27-41.

Sheinbaum J., J. Candela, A. Badan and J. Ochoa, 2002. Flow structure and transport in the Yucatan Channel. Geophys. Res. Lett. 29, doi:10.1029/2001GL013990.

Sturges W., A. Lugo-Fernández (Eds.), 2005. Circulation in the Gulf of Mexico: Observations and models. American Geophysical Union, Washington, DC, doi: 10.1029/161GM01, 347 pp. (Geoph. Monog. Series, 161).

Vázquez de la Cerda A. M, R. O. Reid, S. F. DiMarco and A. E. Jochens, 2005. Bay of Campeche circulation: An update. In: Circulation in the Gulf of Mexico, observations and models (W. Sturges, Ed.). American Geophysical Union, Washington, DC, doi: 10.1029/161GM01, pp. 279-293 (Geoph. Monog. Series, 161).

Villanueva E. E., V. M. Mendoza and J. Adem, 2010. Sea surface temperature and mixed layer depth changes due to cold-air outbreak in the Gulf of Mexico. Atmósfera 23, 325-346.

Walker N., S. Myint, A. Babin and A. Haag, 2003. Advances in satellite radiometry for the surveillance of surface temperatures, ocean eddies and upwelling processes in the Gulf of Mexico using GOES-8 measurements during summer. Geophys. Res. Lett. 30, doi:10.1029/2003GL017555.

Walker N. D, 2005. Seasonal changes in temperatures, shelf and slope circulation and coastal upwelling in the northwestern Gulf of Mexico, and coastal upwelling in the northwestern Gulf of Mexico. In: New developments in the circulation of the Gulf of Mexico (W. Sturges and A. Lugo-Fernández, Eds.). 
American Geophysical Union, Washington, DC, doi:10.1029/161GM16 (Geoph. Monog. Series, 161).

Wang W., W. D. Nowlin Jr. and R. O. Reid, 1998. Analyzed surface meteorological fields over the northwestern Gulf of Mexico for 1992-94: mean, seasonal, and monthly patterns. Mon. Weather Rev. 126, 2864-2883.

Weisberg R. H. and R. He, 2003. Local and deep ocean forcing contributions to anomalous water properties on the West Florida Shelf. J. Geophys. Res. 108, doi:10.1029/2002JC001407.

Weisberg R. H., R. He, Y. Liu and J. I. Virmani, 2005. West Florida shelf circulation on synoptic, seasonal, and interannual time scales. Geog. Monog. Series 161, 325-347.
Zavala-Hidalgo J., A. Parés-Sierra and J. Ochoa, 2002. Seasonal variability of the temperature and heat fluxes in the Gulf of Mexico. Atmósfera 15, 81-104.

Zavala-Hidalgo J., S. L. Morey and J. J. O’Brien, 2003. Seasonal circulation on the western shelf of the Gulf of Mexico using a high-resolution numerical model. J. Geophys. Res. 108, doi:10.1029/2003JC001879.

Zavala-Hidalgo J., B. Martínez, A. Gallegos, S. L. Morey and J. J. O'Brien, 2006. Seasonal upwelling on the western and southern shelves of the Gulf of Mexico. Ocean Dynam. 56, doi:10.1007/s10236006-0072-3.

Zhang Z. and R. D. Hetland, 2012. A numerical study of convergence of alongshore flows over the Texas-Louisiana Shelf. J. Geophys. Res. 117, C11010, doi:10.1029/2012JC008145. 